\title{
FINE AND ULTRAFINE AEROSOL IN OSTRAVA AMBIENT AIR
}

\author{
Karel Lach¹, Karel Klouda², Vladimír Mička', Lucie Hellebrandová1 \\ ${ }^{1}$ Institute of Public Health in Ostrava, Ostrava, Czech Republic \\ 2State Office for Nuclear Safety, Prague, Czech Republic
}

\begin{abstract}
SUMMARY
Air quality in the Moravian-Silesian Region and especially in the Ostrava agglomeration represents a very important factor influencing the environment and health of the local population. The area has been burdend for more than two centuries with rapid development of the mining industry and related metallurgical and chemical production. As a result, hundreds of tons of pollutants have progressively been released into the atmosphere. Some of them have been gradually eliminated from the environment; others, such as some heavy metals, remain locally present and burden the local landscape. Ultrafine particles (UFPs; diameter less than $100 \mathrm{~nm}$ ) are ubiquitous in urban air and an acknowledged risk to human health. Therefore, recurrent situations when statutory limits for airborne dust and selected chemical pollutants are exceeded require more detailed research focused on the sources, paths of propagation, chemical composition and morphology of ultrafine aerosol (UFA). In order to comply with these objectives measurements were carried out directly in production halls and the vicinity of industrial technologies with expected high UFA emission. In line with global trends, focus is increasingly placed on solid aerosols with particle sizes below 1 um and, where appropriate, on nanoparticles. This is mainly due to a much greater penetration of these particles into an organism and a subsequent initiation of some serious diseases.
\end{abstract}

Key words: airborne dust, scanning electron microscopy, particle number concentration, ultrafine aerosol, nanoparticles in the air

Address for correspondence: K. Lach, Institute of Public Health in Ostrava, Partyzánské náměstí 7, 70200 Ostrava 2, Czech Republic. E-mail: karel.lach@zuova.cz.

http://dx.doi.org/10.21101/cejph.a4539

\section{INTRODUCTION}

This article presents some novel viewpoints concerning studies of the emergence and nature of unregulated airborne UFPs. If we want to better understand the health effects associated with the inhalation of ultra-fine dust particles, the "traditional" parameters $\left(\mathrm{PM}_{10}, \mathrm{PM}_{25}\right.$, selected organic pollutants and metals) should be complemented with monitoring of ultra fine particles which significantly influence basic cell functions such as proliferation, metabolism and apoptosis (1-6).

In the case of nanoparticles, the metric of the results (7-9) is still under discussion. Nanotoxicologists are faced with this problem when doses are to be expressed precisely. There are die-hard supporters of mass expression of results, but given the extremely low mass of size fractions below $200 \mathrm{~nm}$ (in relation to $\mathrm{m}^{3}$ ) and their further reductions a different metric is used more frequently when expressing selected size fractions. Contemporary measuring instruments frequently express the number of particles per unit volume in the form of so-called standardized relation $(\mathrm{dN} / \mathrm{d} \log \mathrm{Dp})$, where $\mathrm{N}$ is the number of particles and $\mathrm{Dp}$ is the diameter of the particle(s) $(10,11)$. Another possibility is to express the surface of present nanoparticles to the appropriately selected unit volume. It is assumed that the rate of effect and interaction of nanoparticles with biological tissue (cells and bio-molecules) is always through mutual contact. Therefore, the surface quality of nanoparticles plays a very important role.
Surface wrinkling and creation of active centres together with an electric charge certainly comprise a significant contribution to the initiation of processes that may ultimately lead to severe health problems. Recently published works have expressed the intensity of interactions on the basis of precisely defined chemical reactions between nanoparticles and selected reactants when usually it is the products of oxidation reactions that are most frequently monitored, ideally simulating the occurrence and intensity of oxidative stress (ROS) (12). There are a number of other tests based on the possibility of monitoring changes in biochemical processes or leading to degradation of cellular membranes, DNA or any of the cell organelles $(13,14)$.

If nanoparticles enter the atmosphere, their further transport will be controlled (as in the case of gases due to their very small dimensions) by diffusion from an area with higher concentrations to an area with lower concentrations $(15,16)$. They are further transported by air convection over very long distances. In general, nanoparticles have the primary tendency to group together into larger objects such as various aggregates and clusters. This may cause certain difficulties in measuring the size distribution and will ultimately result in a lower number of calculated nanoparticles and wrongly increased number of calculated micron-sized particles.

In order to evaluate the impact of suspended dust on the environment, public health and, possibly, the definition of probable sources, it is important to ascertain the size distribution of fine and ultra-fine solid aerosol and, where appropriate, the mass 
distribution of selected heavy metals, elementary composition of micron and sub-micron particles and surface texture (morphology) of individual particles. Currently, the first samplings carried out at the stationary measurement sites in Ostrava-Radvanice and Ostrava-Mariánské Hory have indicated a high proportion of UFPs, the source of which is in all probability the iron metallurgical industry. In order to confirm this assumption, the status of one of the representatives of the expected sources of this type of emission was documented. A series of measurements and samplings was carried out directly in the convector hall, the continuous steel casting area and the scarfing machine in the steelworks of Evraz Vítkovice Steel a.s.

\section{MATERIALS AND METHODS}

The measurement of numerical distribution of fine aerosol at workplaces in the steelworks was performed by means of SMPS (Scanning Mobility Particle Sizer) 3934, comprised of the CPC 3022 system (Condensation Particle Counter) working in the low mode and the EC 3071 system (Electrostatic Classifier) equipped with the DMA probe 3081 (Differential Mobility Analyzer) and impactor $0.0457 \mathrm{~cm}$, FMPS (Fast Mobility Particle Sizer, Model 3091,TSI Inc., St. Paul, MN, USA) and Ultrafine Particle Monitor (UFPM) 3031 from TSI Inc. Both cascade impactors Sioutas 225-370 and fractional samplers Nano-ID ${ }^{\circledR}$ Select (Naneum Ltd., UK) were used as samplers for fractional sampling of aerosol. In order to determine the surface of deposited dust particles in the tracheobronchial (TB) and alveolar (A) part of the respiratory tract, mobile equipment Aerotrak 9000 (TSI Inc., St. Paul, MN, USA) was used.

Scanning electron microscopy (SEM) provides very substantial information for the overall evaluation of airborne dust, whether demonstrating the sources of some types of sub-micron particles or their possible nanotoxicology effects. Observations were carried out at SEM (FEI QUANTA 450 FEG, FEI Company, WA, USA) equipped with BSE, LF and Everhardt Thornley (ETD) detectors with EDS and WDS modules for energy-dispersion element analysis and wave-dispersion element analysis respectively. Accessories to this SEM include the module for the so-called "scanning transmission electron microscopy" (STEM). Samples of sub-micron airborne dust fractions were collected by means of the Nano-ID ${ }^{\circledR}$ Select sampler on the so-called TEM grid. Here, attention was paid to fractions ranging from $250 \mathrm{~nm}$ to approximately $20 \mu \mathrm{m}$ (impactor). Fractions greater than $1 \mu \mathrm{m}$ were taken on carbon adhesion tapes. Samplings of fractions below $250 \mathrm{~nm}$ by means of this sampler's diffusion chamber were not sufficiently successful. However, it appeared that much smaller particles are often trapped in fractions between $250 \mathrm{~nm}$ and 500 $\mathrm{nm}$ or that the formed agglomerates of primary nanoparticles can be detected here. The trapped samples without any modifications are directly observable on SEM.

\section{RESULT}

The results of observations in workplaces at the steelworks show that a huge amount of sub-micron particles of spherical shape is emitted in the atmosphere of the converter hall. These are primarily the oxide phase of iron with molar ratio Fe/O approximately equal to the value 0.75 , which is very probably magnetite $\left(\mathrm{Fe}_{3} \mathrm{O}_{4}\right)$. The occurrence of octahedral crystals of magnetite or fully seeded immature crystalline formations of magnetite is also frequently noted.

The appearance and morphology of UFPs occurring in the air near the converter is shown in Figs. 1a and $1 \mathrm{~b}$. In addition to oxide phases of iron, particles of both spherical morphology and different fragmental texture with high carbon content represent another significant proportion. Emissions of metals or their oxides, which enter the air primarily by adding iron scrap, form a separate group. In this case, zinc oxides prevail, Fig. 2. They form very interesting microcrystalline structures, with the smallest size being below $100 \mathrm{~nm}$.

The probable history and the route of formation can be deduced from the morphology of aerosol particles. Where there was a phase change from gaseous state into liquid state at high speed, fine spherical particles are formed, while with sufficient time delay and adequate temperature conditions, crystals of appropriate metal oxides are formed.

Such findings correspond closely to the basic characteristics of behaviour exhibited by sub-micron particles taken both on Zelená Street in Ostrava-Mariánské Hory and in Ostrava-Radvanice city borough. In addition to particles of iron oxides present everywhere, soot (rich in carbon) and clusters of high-carbon particles (Fig. 3) are present. The highly probable source of these must be, given the observed quantity, high-temperature metallurgical
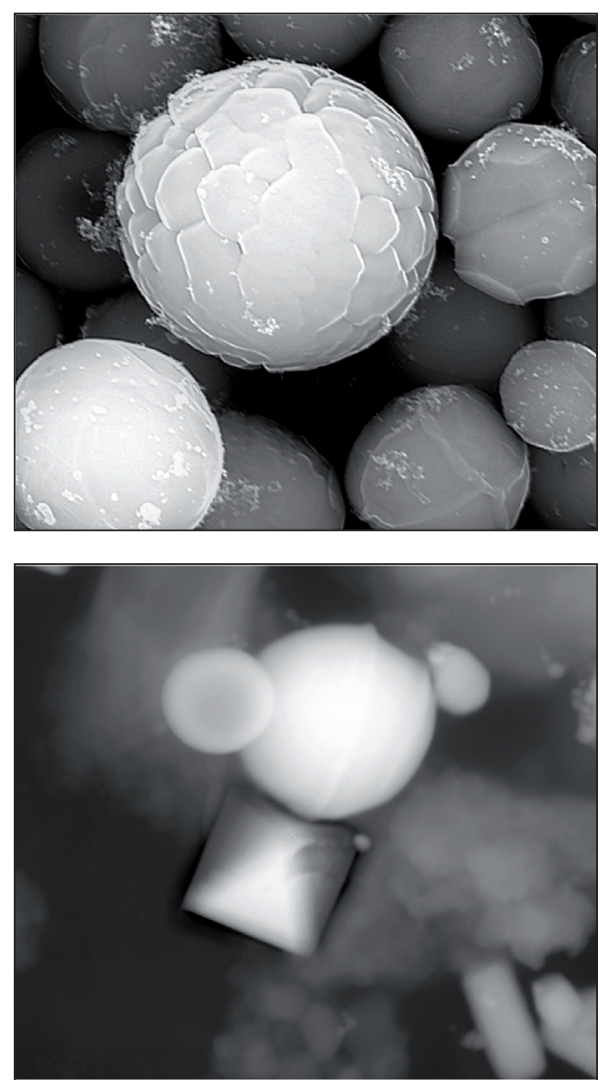

Fig. 1 (a) Typical morphology of dust particles formed by rapid condensation of vapour of molten iron and subsequent oxidation by atmospheric oxygen (trapped spherical oxide phases of iron); (b) appearance of particles with more significant formation of octahedron walls, crystalline texture of magnetite. 


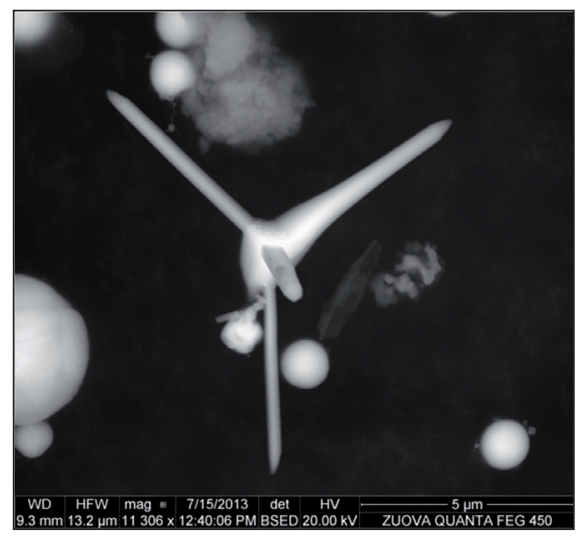

Fig. 2. Microcrystalline textures of zinc oxide in the air around the converter.

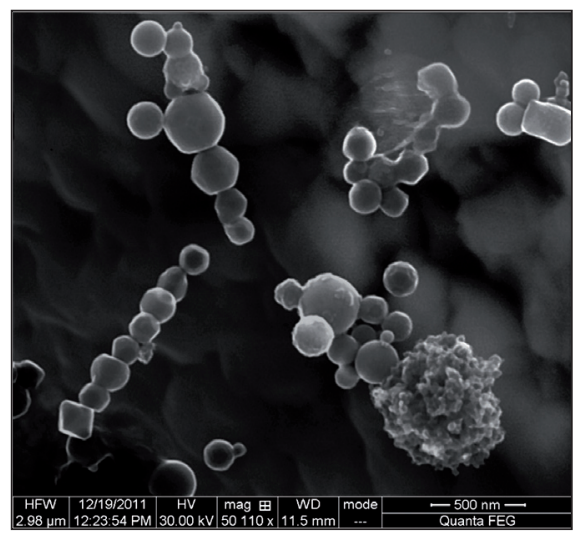

Fig. 3. Morphology of fine and ultra-fine particles of magnetite in Ostrava outdoor air; typical cluster of soot nanoparticles in the bottom right-hand corner.

operations. Iron-oxide particles form linearly interconnected bead textures, the length of which often exceeds several $\mu \mathrm{m}$ and the number of primary particles is in excess of fifty. The magnetic properties of iron are quoted as one of the causes contributing to the formation of such linear clusters. Analysis of particles by means of EDS did not confirm the presence of metals such as chrome and nickel in the samples under examination. In summer months and under favourable meteorological conditions, crystals of sodium chloride are present, originating at sea level in the form of suspended dust. The presence of zinc or zinc oxide particles is also relatively frequently demonstrable.

Measurements by means of FMPS, and on Zelená Street by means of UFPM, were performed at irregular intervals. Distributions of sub-micron nanoparticles are shown as an example of anomalous steep and short-term increase in the concentration of nanoparticles in Fig. 4. UFPM provides continuous information about size distribution ranging from 20 to $1000 \mathrm{~nm}$ in six measuring channels at an interval of 15 minutes. The advantage of this device is the possibility of long-term measurement, which can be performed continuously for up to one month. Fig. 4 presents a one-day record on Zelená Street in Ostrava-Mariánské Hory dated 8 September 2011, when a relatively unexpected shortterm approximately sevenfold increase in the concentration of nanoparticles ranging from 20 to $50 \mathrm{~nm}$ was detected in noon hours. The total concentration is highlighted in bold type. The total short-term concentration of particles in the measured range reached almost 35 thousand $/ \mathrm{cm}^{3}$, with the greatest increase in the measuring range from 30 to $50 \mathrm{~nm}$. The anomaly consists of two maximum values; the modus of the size of particles in both cases is between 30 and $50 \mathrm{~nm}$. The source of this short-term increase in emission of UFPs and the cause have not been identified.

\section{DISCUSSION}

Very similar data were measured by FMPS but only in brief episodes of up to 1 hour. The significant advantage of FMPS is 1 $\mathrm{s}$ response. Even relatively very short variations may be captured with this procedure. The relatively new field of the nanoparticle parameters discussed by toxicologists concerns their surface area concentration as a relevant property for causing inflammation (17). For determining the surface of trapped particles in the human respiratory tract the study used the AEROTRAK ${ }^{\mathrm{TM}} 9000$ Nanoparticle Aerosol Monitor, which is based on diffusion charging of sampled particles, followed by detection of the charged aerosol using an electrometer. The deposition in the human respiratory track is estimated using the ICRP lung deposition model (18). In smog situations the total area of the trapped particles (tracheobronchial + alveolar) exceeds $290 \mu \mathrm{m}^{2} / \mathrm{cm}^{3}$. For comparison, the measured value of the same parameter in the working environment during lead refining was approximately $100 \mu \mathrm{m}^{2} / \mathrm{cm}^{3}$. Air during smog situations may thus be compared to a working environment with a huge occurrence of nanoparticles. Examples of a measurement of the total area of deposited particles in alveolar (A) and tracheobronchial (TB) parts of the human respiratory system are shown in Figs 5a and 5b.

\section{CONCLUSION}

The size distribution of fine and ultra-fine aerosol is a significant pointer for assessing the current situation in the air at sampling sites and their proximity. From a qualitative point of view, fine aerosol in the city of Ostrava is primarily represented by spherical particles and their agglomerates sized below 500 $\mathrm{nm}$ with their composition corresponding to magnetite as well as particles of different shapes, including clusters composed of many thousands of primary nanoparticles and fine foils containing carbon as a majority element, probably soot.

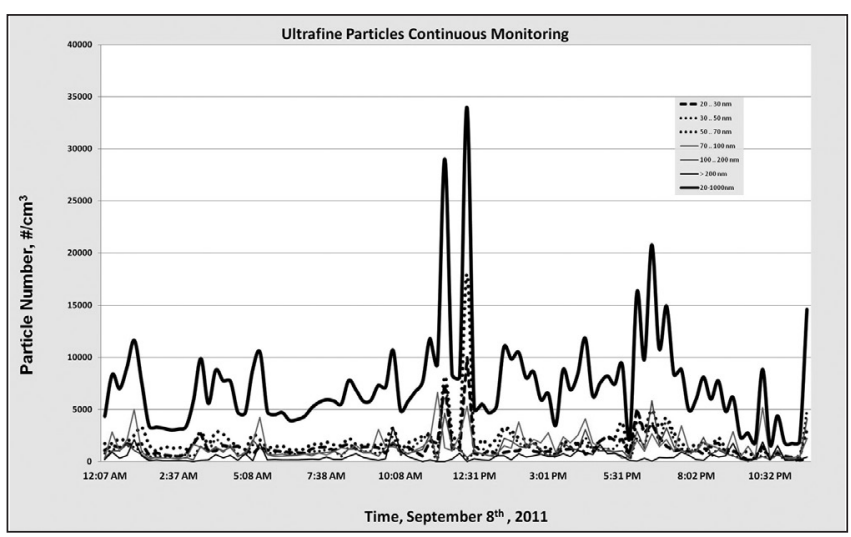

Fig. 4. One-day record of UFPM from all measuring channels including sum of the number of present particles. 

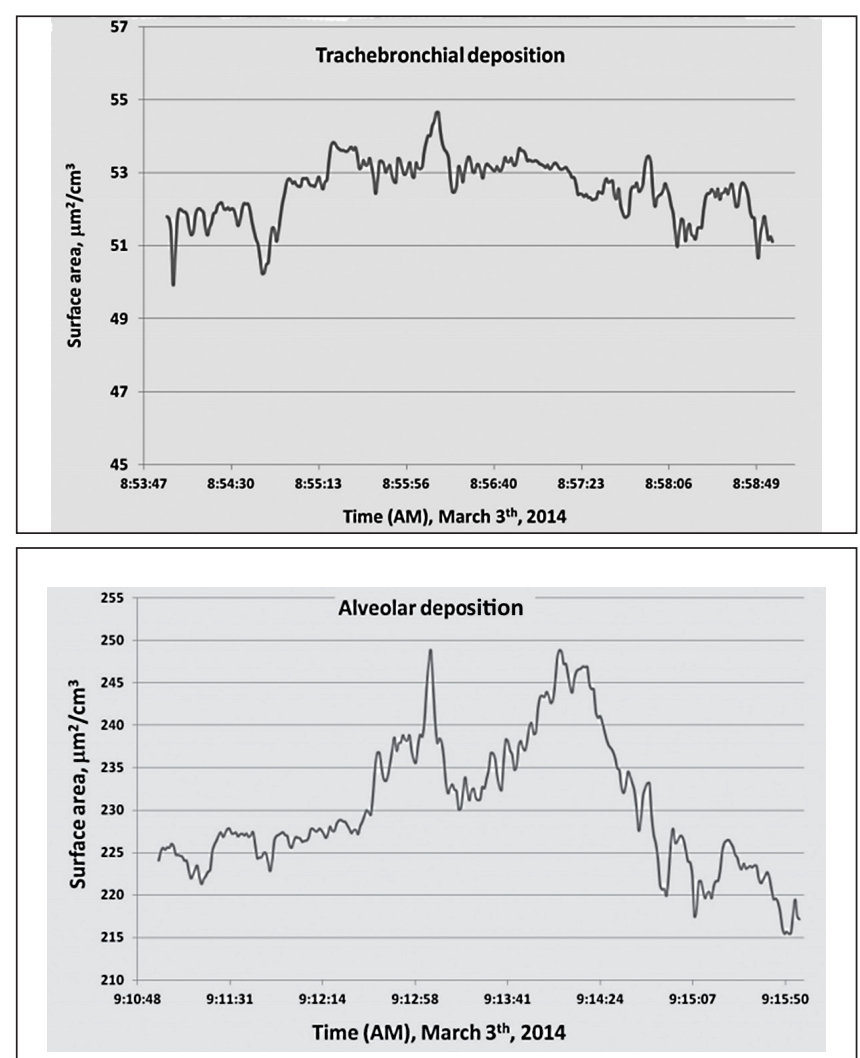

Fig. 5. Tracheobronchial (a), and alveolar (b) surface of nanoparticles area deposition in human respiratory system measured at the Ostrava-Radvanice site.

Short-term to several-week measurements of the occurrence, size distribution and number of fine to ultra-fine aerosol in Ostrava air by UFMP and FMPS show a high burden during periods of poor dispersion conditions. Measurements performed so far have confirmed the high ratio of nanoparticles during smog situations and significantly increased values of $\mathrm{PM}_{2.5}$. Similar episodes usually lasting units of days may occur in summer and mainly autumn months. The noticeable increase in the total number of particles above 50 thousand $/ \mathrm{cm}^{3}$ and ranging $5.6-560 \mathrm{~nm}$ is no exception. Some measurements have demonstrated that there is a certain correlation with the daytime. More frequent increases occur during morning peaks and maximum values often occur at night in connection with the drop in air temperature, and maybe due to failure to comply with technological procedures in nearby metallurgical operations.

\section{Funding}

The Public Health Institute Ostrava financed all expenses associated with measurements and other necessary expenses such as transport of equipment to measurement sites or wages for time spent by two operatives conducting measurements etc. Instruments used for measurements were purchased from project funds pertaining to "Monitoring of nanoparticles in an environment", project number: CZ.1.02/5.1.00/10.06301.

\section{Acknowledgements}

Acknowledgement to employees of EVRAZ Vítkovice Steel a.s., ing. Pavel Škuc and ing. Pavel Večerník for special and technical assistance during measurements in the steelworks.

\section{Conflict of Interests}

None declared

\section{REFERENCES}

1. Braydich-Stolle L, Hussain S, Schlager JJ, Hofmann MC. In vitro cytotoxicity of nanoparticles in mammalian germline stem cells. Toxicol Sci. 2005 Dec;88(2):412-9.

2. Pattan G, Kaul G. Health hazards associated with nanomaterials. Toxicol Ind Health. 2014 Jul;30(6):499-519.

3. Hussain SM, Javorina AK, Schrand AM, Duhart HM, Ali SF, Schlager JJ. The interaction of manganese nanoparticles with PC-12 cells induces dopamine depletion. Toxicol Sci. 2006 Aug;92(2):456-63.

4. Hussain SM, Hess KL, Gearhart JM, Geiss KT, Schlager JJ. In vitro toxicity of nanoparticles in BRL 3A rat liver cells. Toxicol In Vitro. 2005 Oct;19(7):975-83.

5. Liu DD, Zhang JC, Yi CQ, Yang MS. The effects of gold nanoparticles on the proliferation, differentiation, and mineralization function of MC3T3E1 cells in vitro. Chin Sci Bull. 2010 Apr;55(11):1013-9 .

6. Zhao X, Sheng L, Wang L, Hong J, Yu X, Sang X, et al. Retraction Note: Mechanisms of nanosized titanium dioxide-induced testicular oxidative stress and apoptosis in male mice. Part Fibre Toxicol. 2015 Jul 14;12:23.

7. Lison D, Vietti G, van den Brule S. Paracelsus in nanotoxicology. Part Fibre Toxicol. 2014 Aug 12;11:35.

8. Oberdörster G, Oberdörster E, Oberdörster J. Concepts of nanoparticle dose metric and response metric. Environ Health Perspect. 2007 Jun;115(6):A290.

9. Ahmad Khanbeigi R, Kumar A, Sadouki F, Lorenz C, Forbes B, Dailey LA, et al. The delivered dose: Applying particokinetics to in vitro investigations of nanoparticle internalization by macrophages. J Control Release. 2012 Sep 10;162(2):259-66.

10. Ambient air quality monitoring of ultrafine particles in Rochester, New York: final report [Internet]. Albany: New York State Energy Research and Development Authority; 2005 [cited 2016 Mar 27]. Available from: https://www.nyserda.ny.gov/-/media/Files/Publications/Research/Environmental/EMEP/Ambient-Air-Quality-Monitoring-Ultrafine-Particles. pdf.

11. Stanier CO. Ultrafine particles in the atmosphere: formation, emissions and growth [dissertation on the Internet]. Pittsburgh: Carnegie Mellon University; 2003 [cited 2016 Mar 27]. Available from: http://user. engineering.uiowa.edu/ cs_proj/publications/stanier_thesis_all_chapters all appendices optimized.pdf.

12. Sauvain JJ, Deslarzes S, Storti F, Riediker M. Oxidative potential of particles in different occupational environments: a pilot study. Ann Occup Hyg. 2015 Aug;59(7):882-94.

13. Karlsson HL, Cronholm P, Hedberg Y, Tornberg M, De Battice L, Svedhem S, et al. Cell membrane damage and protein interaction induced by copper containing nanoparticles - importance of the metal release process. Toxicology. 2013 Nov 8;313(1):59-69.

14. Shang L, Nienhaus K, Nienhaus GU. Engineered nanoparticles interacting with cells: size matters. J Nanobiotechnology. 2014 Feb 3;12:5.

15. Jaspers I. Fate, transport, and toxicity of engineered nanoparticles in the atmosphere [Internet]. In: Procedings of NSF Nanoscale Science and Engineering Grantees Conference; 2013 Dec 4-6; Arlington, VA, USA [cited 2016 Mar 27]. Available from: http://www.nseresearch.org/2013/ overviews/Ilona_Jaspers Sexton_Jaspers_Kamens_UNC_overview.pdf.

16. Kim KW. Characteristics of nanoparticles in the atmosphere of Gyeongju national park area using PIXE analysis. J Korean Phys Soc. 2007 May;50(5):1584-91.

17. Fissan H, Neumann S, Trampe A, Pui DYH, Shin WG. Rationale and principle of an instrument measuring lung deposited nanoparticle surface area. J Nanopart Res. 2007;9:53-9.

18. Human respiratory tract model for radiological protection. A report of a Task Group of the International Commission on Radiological Protection. Ann ICRP. 1994;24(1-3):1-482. Erratum in: Ann ICRP. 2002;32(1-2):3079. Ann ICRP 1995;25(3-4):iii. 